\title{
My patient the Nazi
}

Previously published at www.cmaj.ca

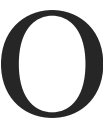

n my first day of internal medicine on my final rotation in medical school, I was asked to assess Mr. K, a man in his mid-80s who had presented in alcohol withdrawal and recovered quickly but, according to the multidisciplinary team, still seemed rather confused. With no known relatives to take care of him, there was some question of whether it was safe to discharge him home. The social worker mentioned that he was a veteran and that she was going to initiate an application to a veteran's home. I went to see him.

Mr. K was a friendly gentleman who smiled and gave me a warm handshake when we met. With no ability to remember names, he would thenceforth refer to me as that "nice boy." When I asked Mr. K how he was feeling, he replied that he felt fine. I was surprised, though, when he added, quite tangentially, that in 1942 he kept a large picture of Adolf Hitler over his bed and was part of an elite Nazi regiment in his home in Austria. Indeed, he actually claimed to have been a member of the SS (whose butchery has made it one of the most notorious organizations in history). "Don't be mad at me," he said. Then, without any prompting from me, he went on to lament the fact that Canada was a democracy. A proper government, Mr. $\mathrm{K}$ said, would take young boys "like you," create a brutal army and dole out lengthy terms of slave labour to troublemakers. At this point, somewhat taken aback, I interrupted Mr. K to conduct a mini-mental status exam, the intended focus of my assessment. His score on that test was well within the range suggestive of severe cognitive impairment, presumably a reflection of dementia. I then asked if he would allow me to examine his chest and

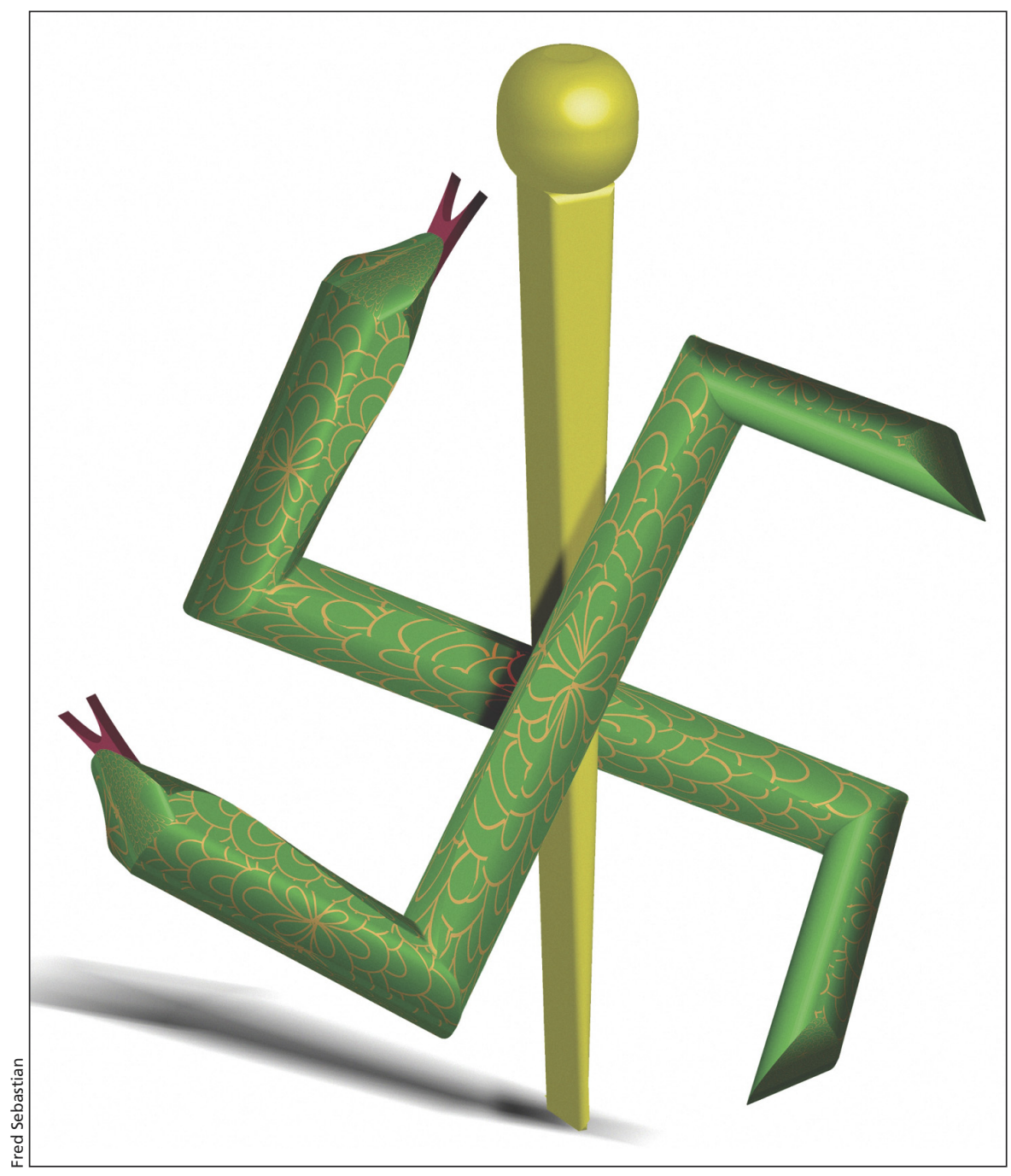

abdomen. He obliged with a smile. When I was finished, I told Mr. K that I would see him tomorrow.

My first thought as I left the man's room was that I did not think he would qualify for veteran's placement. As I put it to the social worker, he had "played for the wrong team." I will tell you now that the rest of this story is not about a brilliant diagnosis. On my final day on service, I left Mr. K as I had found him: confused and waiting for placement at a home, albeit one for nonveterans. Mr. K presented me with a very different challenge from the ordinary. For two and a half weeks I was the primary caregiver and, in many ways, the only advocate in the world for a man whose beliefs and - if true whose past, I found, at best, to be villainous and abhorrent. Dr. Ross Upshur of the University of Toronto's Joint Centre for Bioethics has pointed out to me that this may not be an uncommon circumstance in clinical life, noting that many Médecins Sans Frontières workers were deeply conflicted when members of the Interahamwe, one of the 
militias that perpetrated the Rwandan genocide, took shelter in a MSF aid camp. Still, in my limited experience as a medical student, I had yet to encounter a patient who provoked such a negative gut reaction in me despite my most strenuous efforts to view him through the lens of objectivity.

Let me say, at this point, that I am Jewish. Though my grandparents lived in mortal fear for years under Nazi rule in Romania, in fact my immediate family was comparatively lucky. My wife's family in Poland was almost completely wiped out and I recall numerous stories about various relatives who survived or did not survive concentration camps just over a half century ago. It is my belief that all decent people must fight against racial intolerance. I also believe that as a Jew, a member of a group that has an unfortunate history of senseless persecution at the hands of people like the Nazis, I have a unique responsibility to promote tolerance and equal rights for everyone. While it would be a stretch to say that I chose the field of medicine because of the Holocaust, these beliefs have certainly influenced the decision to devote my life to helping all people regardless of their colour, creed or ethnicity. How then to reconcile my desire was the diagnosis, but it is possible; it was on the differential diagnosis. Could Mr. $\mathrm{K}$ have been a foot soldier, fighting with honour on the front with no idea of the atrocities perpetrated at the death camps at home? Possibly. Could it be more complicated?

One of my medical school colleagues told me a story about a man who had been wheeled into an emergency room in a major American city unconscious. When the staff there saw a large swastika tattooed on the man's chest, they were rough with him, subjected him to inappropriate tests and, to be generous, gave him substandard care. When the man regained consciousness, they discovered that he was an ex-neo Nazi who now devoted himself to speaking at high schools about tolerance. Who was wrong in that instance? Clearly it was the medical team. Primum non nocere - the most basic rule of physician ethics that we learn in medical school is that our first responsibility is not to harm our patients. Doctors are not judges and juries. We are healers who always have to give people the benefit of the doubt. And that is exactly what I did with Mr. K.

In a way, though, this discussion

\section{As a Jew, I have a unique responsibility to promote tolerance and equal rights for everyone. But how can I care for this man?}

to come to the aid of all people with this man who himself embodies the antithesis of that feeling, who in essence I am fighting against?

The easy answer was to rationalize. Is this man really a Jew or Gypsy who was himself persecuted by the Nazis, but who has, in his dementia, taken on the persona of his tormentors? My gut answer to this question is no. But is it possible? Without independent verification of his story, certainly. His descriptions of the war are confused and vague. Given his alcohol history, could this be confabulation as part of WernickeKorsakoff syndrome? In my short time with $\mathrm{Mr}$. K, it was unclear whether this skirts the real issue. If $\mathrm{Mr}$. $\mathrm{K}$ was a known war criminal, would I be morally and ethically bound to treat him as any other patient? In the strictest sense, I suppose that I have to say yes. Difficult as it may be in this case, a physician's obligation and allegiance must first and foremost be to his or her patient. Would I feel comfortable treating him? Absolutely not. In every respect it would be bizarre, but perhaps the solution to my discomfort is in the bizarreness and irony of the situation. It is truly ironic that Mr. $\mathrm{K}$ finds himself infirm of mind in the 21 st century democracy that is Canada. Had he been living under a regime that followed the

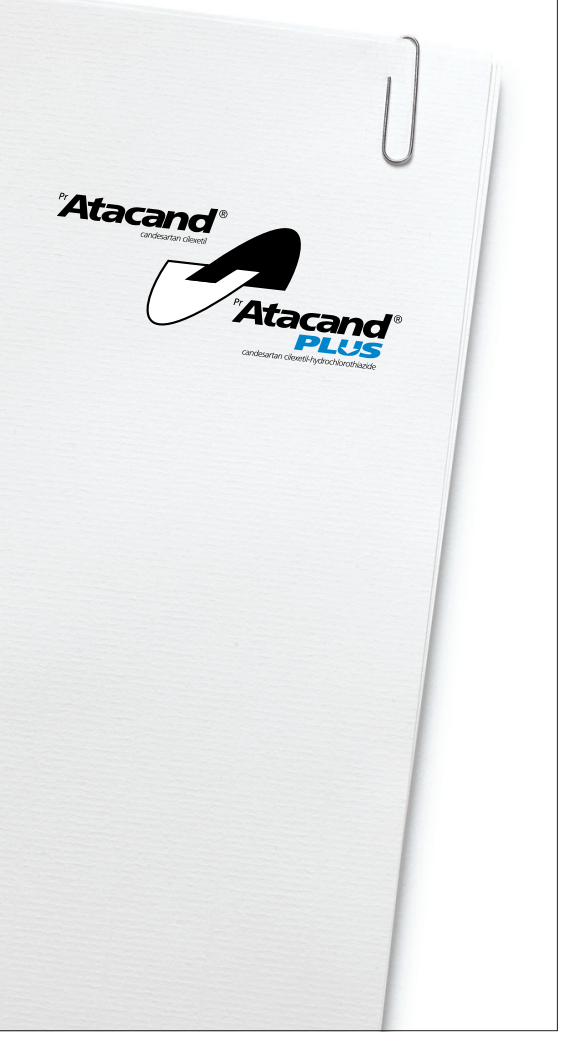

ideology that he appeared to espouse, he very well might have found himself imprisoned or murdered by now. If we, the free world, are to judge totalitarian regimes such as the Nazis by harsh standards then each of us must apply the same standards of liberty to ourselves. If I were to harm Mr. K, a frail old man, in some way, it would diminish me. It would harm my own integrity and humanity in the same way that those emergency medics in trying to harm someone else instead harmed themselves. While it might yield some fleeting satisfaction, it would not be worth it.

I am glad that I live in and contribute to a society that cares for $\mathrm{Mr}$. $\mathrm{K}$ ... whoever he is, whoever he was.

\section{Mark Sinyor MSc MD \\ Resident PGY 3 \\ Department of Psychiatry \\ University of Toronto \\ Toronto, Ont.}

Dr. Sinyor would like to thank Dr. Steven Shumak and Dr. Ross Upshur of Sunnybrook Hospital in Toronto for their advice and guidance on this work. 